\title{
Religion in Macroeconomics:
}

\section{A Quantitative Analysis of Weber's Thesis}

\author{
Tiago V. Cavalcanti Stephen L. Parente Rui Zhao*
}

February 21, 2006

\begin{abstract}
Max Weber in 1905 claimed that Protestantism, and more specifically Calvinism, facilitated the rise of capitalism. This paper assesses the quantitative plausibility of his hypothesis by introducing religious beliefs into a dynamic general equilibrium model of development and growth. Through counterfactual exercises, the paper investigates whether differences between Catholics and Protestants most closely identified with the Protestant Work Ethic can account for long delays in the start of industrialization observed between various countries and regions. The main finding is that these differences may possibly explain why Northern Europe developed before Southern Europe, but they cannot explain why Europe developed before Latin America.
\end{abstract}

JEL Classification Numbers: O11, O41, Z12

Keywords: Religion, Growth, Industrial Revolution

*Cavalcanti: cavalcan@fe.unl.pt, Faculdade de Economia, Universidade NOVA de Lisboa. Parente: parente@uiuc.edu, 343J Wohlers Hall, Department of Economics, University of Illinois at Urbana-Champaign. Zhao: ruizhao@uiuc.edu, 343I Wohlers Hall, Department of Economics, University of Illinois at UrbanaChampaign. We thank Doug Gollin, Larry Neal, Richard Layton, as well as seminar participants at University of Wisconsin Madison and Vanderbilt University for their comments. 
Many of the tenets of Calvinism have had profound social implications-in particular, that thrift, industry, and hard work are forms of moral virtue and that business success is an evidence of God's grace. Because these views helped to create a climate favorable to commerce, Calvinism played a role in the overthrow of feudalism and the establishment of capitalism. Microsoft Encarta

\section{Introduction}

Max Weber in 1905 claimed that Protestantism, and more specifically Calvinism, facilitated the rise of modern capitalism. This paper assesses the quantitative plausibility of his hypothesis by introducing religious beliefs into a dynamic general equilibrium model of development and growth. Through counterfactual exercises, the paper investigates whether differences between Catholics and Protestants can account for long delays in the start of industrialization. The main finding is that they cannot. Differences in religions that primarily affect capital accumulation and work effort account for only a 35-year delay in the start of industrialization.

Our motivation for undertaking these exercises is twofold. First, the idea that an individual's religious beliefs affect his economic actions is almost axiomatic. Weber started his thesis by making this same point: " $(\mathrm{T})$ hough the development of economic rationalism is partly dependent on rational technique and law, it is at the same time determined by the ability and disposition of men to adopt certain types of practical rational conduct" and that "The magical and religious forces, and the ethical ideas of duties based upon them, have in the past always been among the most important formative influences on conduct" (Weber (1958[1905]), p.26). Presumably, different religious beliefs affect various aspects of human conduct differently, a point shown by Guiso, et al. (2003)[14] and reviewed by Iannaccone (1998)[17]. 
Second, Weber's hypothesis continues to be controversial to this day. Within the social sciences, the thesis continues to have strong supporters, despite efforts by individuals such as Tawney (1926)[29] and Samuelsson(1993)[27] to refute it. David Landes (1998)[20], for instance, recently argues that the Protestant work ethic played a critical role in the shift of wealth and power from the south to the north of Europe between the fifteenth and eighteenth centuries.

We attribute the fact that Weber's thesis continues to be controversial nearly one hundred years after its conception to the failure of the social sciences to adequately quantify the effects of religion on the aggregate performance of economies. Curiously enough, Weber himself advocated such a quantitative examination of his hypothesis:

... however, we have no intention whatever of maintaining such a foolish and doctrinaire thesis that the spirit of capitalism could only have arisen as the result of certain effects of the Reformation, or even that capitalism as an economic system is a creation of the reformation. ... On the contrary, we only wish to ascertain whether and to what extent religious forces have taken part in the qualitative formation and the quantitative expansion of that spirit over the world. Weber(1958[1905]) p.91.

This paper sets out to do exactly what Weber himself advocated.

Our paper is certainly not the only recent work that attempts to quantify the importance of religious beliefs. Barro and Mcleary (2003)[2], Guiso, Sapienza, and Zingales (2003)[14], Blum and Dudley (2001)[3], LaPorta, Lopez-de Silanes, Shleifer, and Vishny (1997)[26], and Arrunada (2004)[1] are part of a growing list of papers that weigh in on this issue. To our knowledge, however, ours is the only paper that uses calibration techniques to address this question. Almost all of these other papers employ cross-country "growth" regression 
analysis. ${ }^{1}$ Additionally, with the exception of Blum and Dudley (2001), these papers deal with contemporaneous differences on religion and current outcomes. These papers often reach different conclusion, and thus have failed to settle the controversy surrounding Weber's hypothesis.

The differences we isolate between Catholics and Protestants in this paper relate to the view each religion took toward worldly achievement. For a Catholic, worldly achievement is seen as a barrier to being blessed in the afterlife. For a Protestant, the view is the opposite; worldly achievement is seen as a sign that an individual is to be blessed in the afterlife.

We believe this difference is at the heart of Weber's thesis. Weber interpreted Luther's conception of the "calling", which is at the heart of the Protestant Reformation as the creation of a new standard. That is, he saw "the valuation of the fulfillment of duty in worldly affairs as the highest form which the moral activity of the individual could assume" (Weber (1958[1905])[31], p.80). This new standard manifests itself in Protestantism, in particular Calvinism, through the doctrine of predestination. In Weber's own words, "(t)hus, however, useless good works might be as means of attaining salvation, for even the elect remain beings of the flesh, and everything they do falls infinitely short of the divine standards, nevertheless, they are indispensable as a sign of election. They are the technical means, not of purchasing salvation, but of getting rid of the fear of damnation" (Weber (1958[1905]), p.115). Worldly achievement, therefore, both glorified God and was a sign that an individual was to be blessed in the afterlife.

Catholics took no such view towards daily activity and worldly achievement. As Weber states, "The difference (between Protestants and Catholics) may well be formulated as follows: The normal mediaeval Catholic layman lived ethically, so to speak, from hand to

\footnotetext{
${ }^{1}$ There is also an slightly older, empirical literature that examines the effect of religion on current day outcomes using U.S. micro level data. These include Chiswick (1983)[5], Freeman (1986)[10], and Ellison (1991)[8].
} 
mouth. In the first place he conscientiously fulfilled his traditional duties. But beyond that minimum his good work did not necessarily form a connected, or at least not a rationalized, system of life, but rather remained a succession of individual acts. He could use them as occasion demanded, to atone for particular sins, to better his chances for salvation, or, toward the end of his life, as a sort of insurance premium" (Weber (1958[1905]), p.116). The Catholic Church during the Middle Ages made it clear to its followers that lenders and even shopkeepers risked eternal damnation. ${ }^{2}$ Data cited by Eklund et al (2002) [18] based on Lunt([1934]1965)[21] shows that the indulgence "tax", the nominal sum an individual paid to the Catholic Church to be saved, was increasing in income.

In light of the above discussion, we introduce religious beliefs via a subjective probability of reaching heaven or hell in the afterlife. We do this within the framework of an overlapping generations model augmented with an additional period, which we label the afterlife. ${ }^{3}$ For Protestants, the subjective probability of reaching Heaven is assumed to be increasing in the wealth an individual accumulates during his lifetime. For Catholics, the opposite is true. The wealth an individual accumulates during his lifetime depends directly on his saving decision, (thrift), and indirectly on his labor supply decision, (work effort).

The development model we use is that of Hansen and Prescott (2002)[16]. That model associates the start of an industrial revolution with the date on which an economy switches from a Malthusian production technology with a fixed factor of production, land, to a Solow production technology, with no fixed factors of production. That model has been shown both by Ngai (1999)[23] and Parente and Prescott (2005)[25] to successfully account for the evolution of international income levels since 1750 .

Essentially, we follow their approach, but instead of assuming countries differ historically

\footnotetext{
${ }^{2}$ See Fullerton[11], page 9.

${ }^{3}$ Azzi and Ehrenberg (1975)[4] introduced religion in a similar fashion. Their goal was to explain church attendance and contributions.
} 
in secular policies, we assume that countries differ historically in their religious beliefs. We calibrate the model to the development experience of England over the 1600-2000 period assuming the Protestant belief established itself there in 1645. The counterfactual exercise we undertake is to suppose that England had stayed a Catholic country after 1645, and to determine how much, if it all, its industrial revolution would have been delayed. We find that Catholicism might have delayed the start of the Industrial Revolution in England by 35 years.

The paper is organized as follows. Section 2 describes the model economy. Section 3 defines and characterizes the competitive equilibrium path. Section 4 calibrates the model and quantifies the effect of religious differences on the start of the industrial revolution. Section 5 proceeds with a sensitivity analysis. Section 6 concludes the paper.

\section{Model Economy}

The economy is populated by overlapping generations, each of which lives two periods. There is a single production commodity that can be used for both consumption and investment purposes. This good can be produced with either a traditional technology or a modern technology. Only the traditional technology uses a fixed factor, land. Both technologies exhibit constant returns to scale and are subject to exogenous technological change. Firms purchase labor services from young agents and capital and rental services from old agents. When young, an individual earns labor income and accumulates assets both in the form of land and capital. The utility of an individual not only depends on the consumption he enjoys when young and old, but also on his religious beliefs concerning the afterlife. An agent's religion determines whether the probability he assigns to going to heaven in the afterlife increases or decreases in his worldly achievements. We now describe in more detail the structure of the economy. 


\subsection{Technology}

The composite good can be produced with either of two technologies-the Malthusian technology and the Solow technology. The Malthusian technology is a traditional technology that uses capital, labor, and land as inputs denoted by $K_{M t}, H_{M t}$, and $L_{M t}$ respectively. The Solow technology is a modern technology that uses capital and labor as inputs, denoted by $K_{S t}$, and $H_{S t}$. Both technologies take Cobb-Douglas forms. More specifically,

$$
\begin{aligned}
\text { Malthus } & Y_{M t}=A_{M t} K_{M t}^{\phi} H_{M t}^{\mu} L_{M t}^{1-\phi-\mu}, \\
\text { Solow } & Y_{S t}=A_{S t} K_{S t}^{\theta} H_{S t}^{1-\theta} .
\end{aligned}
$$

The total factor productivity (TFP) of the Malthus technology, $A_{M t}$, and the total factor productivity of the Solow technology, $A_{S t}$, evolve according to the following laws of motion:

$$
\begin{aligned}
\text { Malthus } & A_{M t}=A_{M 1}\left(1+\gamma_{M}\right)^{t-1}, \\
\text { Solow } & A_{S t}=A_{S 1}\left(1+\gamma_{S}\right)^{t-1}
\end{aligned}
$$

\subsection{Endowments}

Households live for two periods. When young, each household is endowed with one unit of time. Additionally, the initial old are each endowed with $k_{1}$ units of capital, and $l_{1}$ units of land. The total endowment of land in the economy is normalized to 1. Land does not depreciate. Capital, in contrast, depreciates fully, as the empirical counterpart of a model period is 35 years.

\section{$2.3 \quad$ Preferences}

The utility of a household depends on both the consumption and leisure he enjoys while alive, and the state he expects to realize in the afterlife. 


\section{This Life}

During its lifetime a household derives utility from consumption when young and when old, and leisure when young. Let $c_{1 t}$ denote the consumption of the household born at time $t$ when young, $c_{2 t}$ his consumption when old, and $1-h_{t}$ his leisure when young. We introduce leisure into the household's utility to allow for the possibility that differences in religious beliefs have an impact on the hours the young household works. Households discount the future with subjective discount factor $\beta$.

\section{The Afterlife}

A household is either Catholic or Protestant in its beliefs. Both Protestant and Catholic households believe in the existence of an afterlife, and associate a value of utility to ending up in the good state, heaven, and a value of utility to ending up in the bad state, hell. ${ }^{4}$ For simplicity, we assume that both religions assign the same utility value to going to heaven and the same utility value to going to hell. We denote the utility of going to heaven by $V^{H}$, the utility of going to hell by $V_{H}$, and their difference by $V$, (i.e., $V=V^{H}-V_{H}$ ).

Differences in the two religions manifest themselves in the likelihoods households assign to achieving the good and bad states. Following Weber (1905), we assume that Catholics believe that economic achievement during one's lifetime decreases the probability of going to heaven whereas Protestants believe the opposite. Let $x_{t}$ denote a household's economic achievement in his lifetime relative to the economic achievement of the previous generation, and let Catholic and Protestant subjective beliefs be given by the functions $\pi^{C}(x)$ and $\pi^{P}(x)$. The main difference then between the two religions is that $d \pi^{C}(x) / d x \leq 0$ and $d \pi^{P}(x) / d x \geq 0$.

\footnotetext{
${ }^{4}$ We do not consider the possibility that there is a third state, limbus, or that households can move between states in the afterlife.
} 
The following functional forms are chosen for computational convenience ${ }^{5}$ :

$$
\pi^{C}(x)=\left\{\begin{array}{ll}
1, & x \in[0,1) \\
1-\alpha \ln x, & x \in\left(1, e^{\frac{1}{\alpha}}\right] \\
0, & x \in\left(e^{\frac{1}{\alpha}}, \infty\right)
\end{array} \quad \pi^{P}(x)= \begin{cases}0, & x \in[0,1) \\
\alpha \ln x, & x \in\left(1, e^{\frac{1}{\alpha}}\right] \\
1, & x \in\left(e^{\frac{1}{\alpha}}, \infty\right)\end{cases}\right.
$$

To guarantee an interior solution to the household's problem, we impose two restrictions on religious parameters, $\alpha$ and $V:(1) \alpha V<1 / \beta$; (2) $\alpha>0$ but sufficiently small so that $0<\alpha \ln x<1$ at any period.

Total Utility

The expected discounted utility of a young household of religion $i$ born at date $t$ is

$$
\ln \left(c_{1 t}\right)+\eta \ln \left(1-h_{t}\right)+\beta \ln \left(c_{2 t}\right)+\beta^{2}\left[\pi^{i}\left(x_{t}\right) V^{H}+\left(1-\pi^{i}\left(x_{t}\right)\right) V_{H}\right]
$$

\subsection{Demographics}

Let $N_{t}$ denote the number of households born in period $t$. At $t=1$, there are $N_{0}$ number of old households and $N_{1}$ number of young households alive. Population growth between periods $t$ and $t+1$ is a function of the average consumption of young agents in the economy in period $t$. Let $g$ denote this function, then

$$
N_{t+1}=g\left(c_{1 t}\right) N_{t}
$$

Population growth in this model reflects the choice of society, rather than individual households. ${ }^{6}$ For this reason, a young household does not take into account the effect of

\footnotetext{
${ }^{5}$ The log function is chosen to simplify the computation. As any well-defined probability function must be bounded between values of 0 and 1 , it is necessary to constraint the domain of the logarithmic function. This explains why the subjective probability depends on relative wealth, not absolute wealth, as absolute wealth is unbounded in a model of growth

${ }^{6}$ For a description of this societal theory of population growth see Parente and Prescott (2005).
} 
its consumption choice on population. For this reason too, societies can differ along this dimension, possibly because of the religions followed by the majority of their populations.

\section{Competitive Equilibrium}

\subsection{Profit Maximization}

The profit maximization problem of a firm that uses either the Malthusian technology or the Solow technology is static. Neither capital nor labor is technology specific. Thus, the rental prices of capital and labor faced by a firm do not depend on the technology it uses. Let $w_{t}$ be the rental price of land, $r_{K t}$ be the rental price of capital, and $r_{L t}$ be the rental price of land at date $t$. The problem of the stand in firm that uses the Malthusian technology is

$$
\max _{H_{M t}, K_{M t}, L_{M t}} A_{M t} K_{M t}^{\phi} H_{M t}^{\mu} L_{M t}^{1-\phi-\mu}-w_{t} H_{M t}-r_{K t} K_{M t}-r_{L t} L_{M t}
$$

and the problem of the stand in firm that uses the Solow technology is

$$
\max _{H_{S t}, K_{S t}} A_{S t} K_{S t}^{\theta} H_{S t}^{1-\theta}-w_{t} H_{S t}-r_{K t} K_{S t}
$$

Because land is supplied inelastically in the economy and is not used in the Solow technology, the Malthusian technology will be operated in all periods. Profit maximization implies that

$$
\begin{aligned}
& w_{t}=\mu A_{M t} K_{M t}^{\phi} H_{M t}^{\mu-1} L_{M t}^{1-\phi-\mu}, \\
& r_{K t}=\phi A_{M t} K_{M t}^{\phi-1} H_{M t}^{\mu} L_{M t}^{1-\phi-\mu}, \\
& r_{L t}=(1-\phi-\mu) A_{M t} K_{M t}^{\phi} H_{M t}^{\mu} L_{M t}^{-\phi-\mu} .
\end{aligned}
$$

The Solow technology, in contrast, need not be used in a given period. The Solow technology will not be used if the profits associated with operating that technology are negative. Profits are negative if and only if

$$
A_{S t}<\left(\frac{w_{t}}{1-\theta}\right)^{1-\theta}\left(\frac{r_{K t}}{\theta}\right)^{\theta}
$$


Equation (10) states that when TFP of the Solow technology is too low, the unit cost of producing the composite good using the Solow technology exceeds one, thereby implying negative profits. The period when the Solow technology is first operated is called the takeoff date. After the take-off date, profit maximization of the stand in firm using the Solow technology implies the following:

$$
\begin{aligned}
& w_{t}=(1-\theta) A_{S t} K_{S t}^{\theta} H_{S t}^{-\theta}, \\
& r_{K t}=\theta A_{S t} K_{S t}^{\theta-1} H_{S t}^{1-\theta} .
\end{aligned}
$$

\subsection{Utility Maximization}

Given the endowment pattern, a young household's sole source of income is his labor earnings. An old household, in contrast, derives income from renting the capital and land he accumulated when young. Additionally, an old household derives income from selling his land holdings.

Old Alive at date 1

The old alive at date $t=1$ have no decisions to make. They simply consume their entire income. The budget constraint of the initial old is

$$
c_{20}=r_{K 1} k_{1}+\left(q_{1}+r_{L 1}\right) l_{1}
$$

\section{Young Date $t$ Generation}

A household only works when young. A young household consumes part of this income and saves the other part in the form of capital and land. Consumption when old is financed by the proceeds from his savings. Let $k_{t+1}$ denote a young household's savings held in the form of capital and $l_{t+1}$ his savings in the form of land. Let $q_{t}$ denote the sale price of land at time $t$. As the empirical counterpart of a period in the model is approximately 35 years, the household's capital fully depreciates after a period. The budget constraints of a household 
born at time $t$ are

$$
\begin{aligned}
& c_{1 t}+k_{t+1}+q_{t} l_{t+1}=w_{t} h_{t}, \\
& c_{2 t}=r_{K t+1} k_{t+1}+\left(q_{t+1}+r_{L t+1}\right) l_{t+1} .
\end{aligned}
$$

Let $a_{t}$ denote the value of wealth accumulated by a household born in period t, namely,

$$
a_{t}=r_{K t+1} k_{t+1}+\left(q_{t+1}+r_{L t+1}\right) l_{t+1}
$$

and define the household's relative economic achievement as

$$
x_{t}=\frac{a_{t}}{a_{t-1}} .
$$

A young household born at date $t$ chooses a vector $\left(c_{1 t}, c_{2 t}, h_{t}, k_{t+1}, l_{t+1}, a_{t}, x_{t}\right)$ to maximize equation (5) subject to budget constraints (13) and (14), and subject to wealth equations (15) and (16). Because $a_{t}$ equals $c_{2 t}$, we restrict $\alpha V<1 / \beta$ so that the effect of an increase in $c_{2 t}$ on expected utility is positive for a person with Catholic beliefs.

The following no-arbitrage condition ensures that households will hold both capital and land in the equilibrium,

$$
q_{t+1}=r_{K t+1} q_{t}-r_{L t+1} .
$$

Our preference specification allows us to derive a closed form interior solution to the household's problem. Under the restrictions imposed on parameters $\alpha$ and $V$, the optimal choice of a young household of either religion is such that the probability of going to heaven and the probability of going to hell are both non-zero in all periods. Let $\beta^{i}$ denote the modified discount factor of a household with belief $i \in\{C, P\}$. Define $\beta^{C} \equiv \beta-\beta^{2} \alpha V$ and $\beta^{P} \equiv \beta+\beta^{2} \alpha V$. Obviously $\beta^{P}>\beta^{C}$. The utility maximizing consumption and leisure 
allocations of a household born in date $t$ with belief $i$ must satisfy

$$
\begin{aligned}
c_{1 t}^{i} & =\frac{w_{t} h_{t}^{i}}{1+\beta^{i}}, \\
c_{2 t}^{i} & =r_{K t+1} \beta^{i} c_{1 t}^{i}, \\
h_{t}^{i} & =\frac{1+\beta^{i}}{1+\eta+\beta^{i}} .
\end{aligned}
$$

Equation (18) implies that the savings rate of the young household of religion $i$ is constant

and equal to $\frac{\beta^{i}}{1+\beta^{i}}$. Equation (20) shows that the numbers of hours worked by each young household does not vary over time. Clearly, a Protestant is more thrifty compared to a Catholic, as the former saves a larger proportion of his labor income. A Protestant also has a greater work effort compared to a Catholic as the former works more hours when young.

\subsection{Market Clearing}

There are five markets in each period: the goods market, the labor market, the capital market, the land rental market, and the real estate market. The following 5 equations are the associated market clearing conditions:

$$
\begin{aligned}
& N_{t} k_{t+1}+N_{t} c_{1 t}+N_{t-1} c_{2 t-1}=Y_{M t}+Y_{S t} \\
& N_{t} h_{t}=H_{M t}+H_{S t} \\
& N_{t-1} k_{t}=K_{M t}+K_{S t} \\
& N_{t-1} l_{t}=L_{M t} \\
& N_{t} l_{t+1}=N_{t-1} l_{t}
\end{aligned}
$$

\subsection{Definition of a Competitive Equilibrium}

A competitive equilibrium in which the economy starts out specializing in the Malthusian technology is a consumption of the initial old, $c_{20}$, a sequence of young household choices, 
$\left\{c_{1 t}, c_{2 t}, h_{t}, k_{t+1}, l_{t+1}, a_{t}, x_{t}\right\}_{t=1}^{\infty}$, a sequence of choices for firms using the Malthusian technology, $\left\{H_{M t}, K_{M t}, L_{M t}\right\}_{t=1}^{\infty}$, a sequence of choices for firms using the Solow technology, $\left\{H_{S t}, K_{S t}\right\}_{t=1}^{\infty}$, and a take-off date $t^{*}>1$ that satisfy

i. profit maximization

(a) for $t<t^{*}$, equations (7)-(9) and (10).

(b) for $t \geq t^{*}$, equations (7)-(9), (11 )-(12), and (10) with equality.

ii. utility maximization

(a) for all $t>1$, equations (18)-(20).

(b) the budget constraint of the old alive at date 1 .

iii. market clearing equations (21)-(25)

\subsection{Properties of the Equilibrium}

The qualitative properties of the model are the same as in Hansen and Prescott (2002); the addition of religious beliefs does not change the nature of the equilibrium path. The economy will start out specializing in the Malthusian technology, provided a sufficiently small initial TFP in the Solow technology, $A_{S 1}$. As long as $\gamma_{S}>0$, the Solow technology will come to be used at some date, after which, sustained growth in per capita output occurs. Provided that the population growth function $g\left(c_{1 t}\right)$ is a constant for sufficiently large values of $c_{1 t}$, the economy will converge to the balanced growth path of the standard Solow model with a constant growth rate of per capita output equal to $\left(1+\gamma_{S}\right)^{1 /(1-\theta)}$. Asymptotically, economies with different religious beliefs, therefore, will grow at the same rate.

Differences in religious beliefs will work to affect the dates at which economies start to experience sustained growth in output per capita through thrift and work effort. By 
assumption, TFP in the Solow technology does not vary across countries. Consequently, it follows from equation (10) that any difference in take-off dates is attributed to differences in rental prices, which are affected by the economy's capital and labor inputs. More capital (thrift) and more labor (work ethic) will both accelerate the take-off date, as they reduce the wage rate and interest rate in the economy, thereby reducing the unit cost of production using the Solow technology.

From equation (20), one can see that the labor input in a Protestant economy is higher than the labor input in a Catholic economy, and from equation (18), one can see that the savings rate of the young is also higher in a Protestant economy. The latter suggests that the Protestant economy has a higher capital stock at any given date. ${ }^{7}$ These factors imply that a Protestant economy will start the development process before a Catholic economy. The key question is whether differences in religious beliefs are quantitatively important.

\section{Computation}

\subsection{Calibration}

The quantitative importance of religious beliefs for development and growth is determined by parameterizing the model and comparing the computed equilibrium paths for Catholic and Protestant economies. The question we precisely answer in this experiment is how much later would the Industrial Revolution have started in England if it had not undergone the Protestant Reformation and continued as an essentially Catholic nation. ${ }^{8}$

\footnotetext{
${ }^{7}$ This can only be verified via numerical solutions, however. The numerical solution is needed because households also save in the form of land.

${ }^{8}$ We make no claim that the difference between Protestants and Catholics isolated in this paper exists today. For this reason our analysis focuses on delays in the start of the development process, rather than current differences in income levels.
} 
The calibration is based on an interpretation that pre-1645 England was a Catholic nation on a Malthusian steady state and post-1645 England was a Protestant nation. ${ }^{9}$ Additionally, the calibration is based on a 1750 starting date for the Industrial Revolution in England. Lastly, the calibration is based on an interpretation that post-1850 England was close to or on a Solow balanced growth path.

Accordingly, period 1 in the model corresponds to the year 1645, the date of the Protestant Reformation in England. Without loss of generality, the initial population of the young, $N_{1}$, and the initial level of TFP for the Malthusian technology, $A_{M 1}$, are normalized to 1 . The initial level of TFP for the Solow technology, $A_{S 1}$ is set so that the model economy begins to use the Solow technology at $t=4$, which given the empirical counterpart of a model period is 35 years, implies a 1750 start of the industrial revolution. The initial population of the old, $N_{0}$ and the initial capital stock, $K_{1}$ are set at the values associated with the Malthusian steady state with Catholic beliefs. ${ }^{10}$

The parameters associated with the Malthusian technology are restricted so that the Malthusian steady state with Catholic beliefs is consistent with pre-1645 English observations. Values for the coefficients on capital and labor, $\phi$ and $\mu$, are based on historical estimates of capital and labor shares of income by Clark (1998)[6]. The growth rate of TFP in the Malthusian technology, $\gamma_{M}$, is restricted to match England's population growth in the Middle Ages as reported by Maddison (1995)[22]. The reason why the observation for population growth determines the growth rate of TFP is that at the Malthusian steady state,

\footnotetext{
${ }^{9}$ Historically, Puritanism developed and briefly achieved dominance in England during the period when the monarchy was suspended under Oliver Cromwell. The Westminster Confession (1646) represents the systematic expression of Puritan theology. It was adopted by the Church of Scotland in 1648 and has become the basic creed of Presbyterian groups in Britain and throughout the world.

${ }^{10}$ The Malthusian steady-state is the steady state equilibrium for the model economy in which only the Malthusian technology is available for use. See Hansen and Prescott (2002) for a detailed description.
} 
increases in output attributed to increases in TFP are exactly offset by increases in the population. As a result, output per capita is constant. More specifically, $1+\gamma_{M}=\left(1+g_{M n}\right)^{1-\phi-\mu}$, where $g_{M n}$ is the period average rate of population growth for England in the Middle Ages.

The parameters associated with the Solow technology, are restricted so that the Solow balanced growth path is consistent with post-1850 observations. The coefficient on capital, $\theta$, is set to match physical capital's share of income as reported by Hansen and Prescott (2002)[16]. ${ }^{11}$ The growth rate of TFP in the Solow technology, $\gamma_{S}$, is restricted so that the average annual growth rate of per capita output in the model economy matches England's average annual growth rate since 1900 .

The product of religious parameters, $\alpha V$, as well as preference parameters, $\beta$ and $\eta$, are calibrated to match pre-1645 hours worked and post 1850- hours worked reported by Clark and van der Werf (1998)[7], and estimates of the post-1850 capital to output ratio reported by Feinstein (1978, p. 84)[9] and by Maddison (1995, p. 65). The pre-1645 hours correspond to the labor input of a young Catholic household and the post-1850 hours correspond to the labor input of a young Protestant household. ${ }^{12}$ The religious belief parameters, $\alpha$ and $V$, cannot be identified separately. ${ }^{13}$ The value of $\alpha$, however, is set at a sufficiently small

\footnotetext{
${ }^{11}$ The capital share observation parameter is actually based on postwar US data. However, capital's share has been shown by Gollin (2002)[12] to be roughly constant across countries.

${ }^{12}$ More specifically, the three equations used in calibration are

$$
\begin{aligned}
& \frac{1+\beta-\beta^{2} \alpha V}{1+\eta+\beta-\beta^{2} \alpha V}=\text { pre-1645 labor supply, } \\
& \frac{1+\beta+\beta^{2} \alpha V}{1+\eta+\beta+\beta^{2} \alpha V}=\text { post-1850 labor supply, } \\
& \frac{(1-\theta)\left(\beta+\beta^{2} \alpha V\right)}{\left(1+\beta+\beta^{2} \alpha V\right)\left(1+\gamma_{s}\right)^{\frac{1}{1-\theta}}\left(1+g_{S n}\right)}=\text { post-1850 capital-output ratio. }
\end{aligned}
$$

${ }^{13}$ Although the values of $\alpha$ and $V$ cannot be identified separately in our model, they do have very different interpretations. Parameter $\alpha$ measures the increase or decrease in the probability of going to heaven when
} 
Figure 1: Population Growth Function

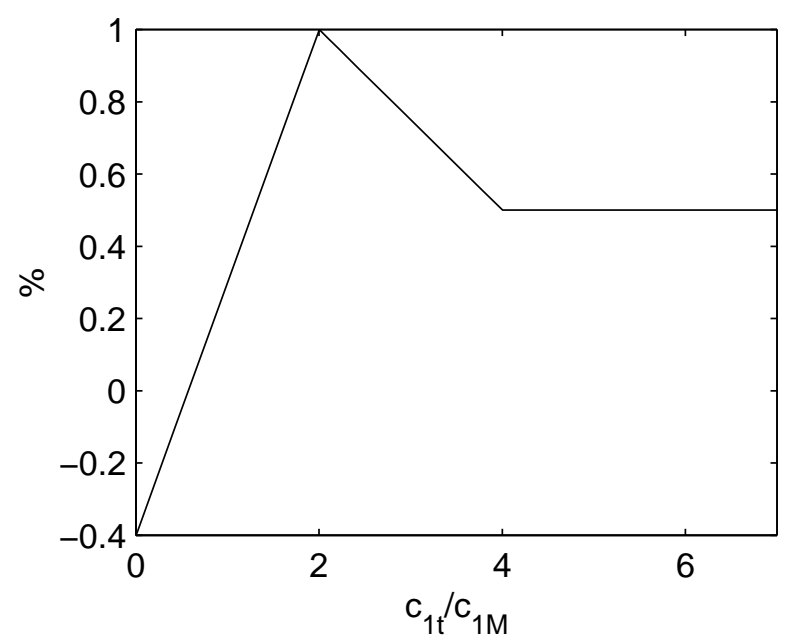

positive value to ensure interior solutions.

The population growth function, $g\left(c_{1 t}\right)$ is restricted to roughly match English population growth rates from 1645 to 1990 reported by Maddison (1995), and to ensure that the model is consistent with the existence of a globally stable Malthusian steady state. The latter requires that $g(0)$ be sufficiently small, $g\left(c_{1 M}\right)$ equals the population growth rate of England in the Middle Ages, where $c_{1 M}$ is the consumption of the young at the Malthusian steady state with Catholic beliefs, and $g^{\prime}\left(c_{1 t}\right)>0$ for all $c_{1 t}$ in the neighborhood $c_{1 M}$. Additionally, to ensure that the economy will converge to the balanced growth path associated with the Solow technology, $g\left(c_{1 t}\right)$ is restricted to be constant for $c_{1 t}>c^{*}$, where $c^{*}$ is a large number. Figure 1 plots the population growth function used in the simulations.

Table 1 lists the parameter values and provides comments.

the growth rate of consumption increases by one percent. Parameter $V$, in contrast, measures the fear of hell relative to the prospect of heaven. 
Table 1: Parameter Values

\begin{tabular}{|c|c|c|}
\hline Parameters & Values & Comment/Observation \\
\hline$\phi$ & 0.100 & Pre-1645 capital share based on Clark (1998a) \\
\hline$\mu$ & 0.600 & Pre-1645 Labor Share based on Clark(1998a) \\
\hline$\theta$ & 0.400 & $\begin{array}{l}\text { Post-1850 capital share reported by Hansen and Prescott } \\
(2002)\end{array}$ \\
\hline$\gamma_{M}$ & 0.032 & $\begin{array}{l}0.3 \% \text { Average annual population growth for England } \\
\text { prior to } 1645 \text { based on Maddison (1995) }\end{array}$ \\
\hline$\gamma_{S}$ & 0.367 & $\begin{array}{l}\text { 1.5\% Post-1850 English annual growth rate of per capita } \\
\text { output based on Maddison (1995) }\end{array}$ \\
\hline$\eta$ & 0.415 & 266 and 300 days worked in $1600-1640$ and $1850-1900$ \\
\hline$\beta$ & 0.514 & as reported by Clark and Van Der Werf (1998) and \\
\hline$\alpha \cdot V$ & 1.515 & $\begin{array}{l}2.5 \text { capital-output ratio based on estimates of Feinstein } \\
\text { (1978) and Maddison (1995) }\end{array}$ \\
\hline$\alpha$ & 0.649 & $\begin{array}{l}\text { Consistent with non-zero probability of going to heaven } \\
\text { and non-zero probability of going to hell. }\end{array}$ \\
\hline$A_{S 1}$ & 0.600 & 1750 Start of Industrial Revolution \\
\hline
\end{tabular}


Figure 2: Growth Experience of the Protestant England

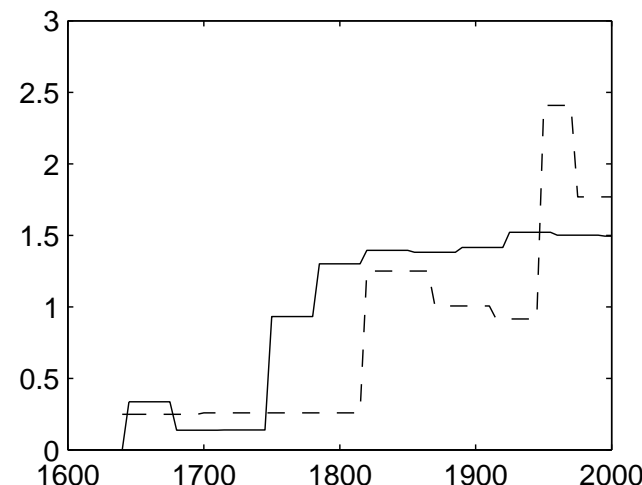

(a) Growth rate of output per capita

- Simulated

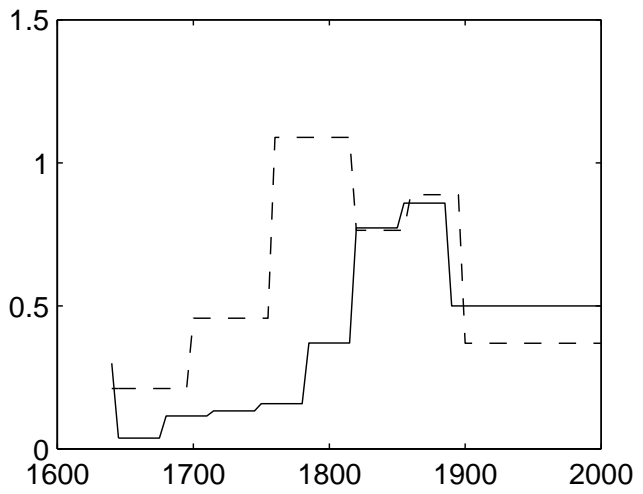

(b) Growth rate of population

\subsection{Development Path of Protestant England}

We find that the introduction of leisure and religious beliefs to the household's preferences does not substantially alter the quantitative properties of the development and growth path. ${ }^{14}$ The industrial revolution, namely, the transition from Malthus to Solow takes a long period of time to complete; nearly 105 years elapse before 95 percent of the economy's output is produced with the Solow technology.

The equilibrium path is quantitatively contrasted with England's development experience in Figures 2. The model roughly matches the increases in livings standards (Figure 2(a)) in England over this time as well as its population dynamics (Figure 2(b)). Prior to 1750, the growth rate of per capita is low and irregular, but thereafter increases dramatically before leveling off to 1.5 percent. It does not match England's population dynamics exactly. While it is off on the timing of changes, it does generate the same pattern for the population growth rate.

\footnotetext{
${ }^{14}$ The equilibrium path is computed using the shooting algorithm described in Hansen and Prescott (2002).
} 
Figure 3: The Would-be Delay of the Economic Development of England

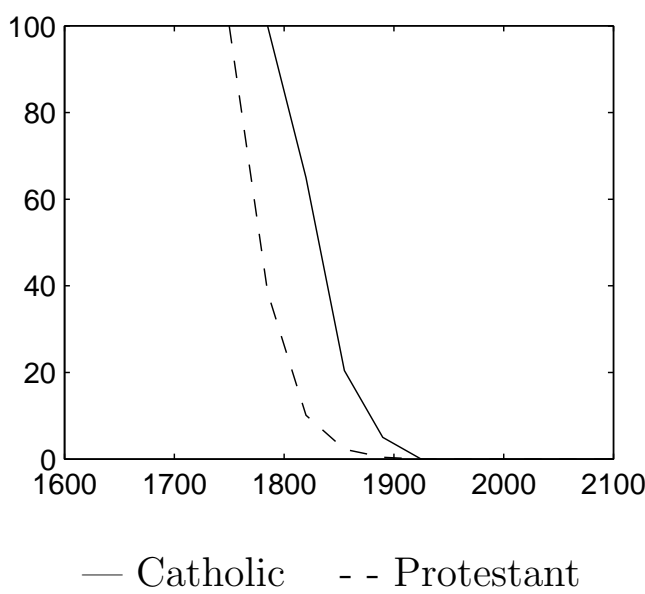

\subsection{Delays in Development}

To quantify the effect of religion on development, we compute the development path for a Catholic economy with the same initial conditions and compare it to the development path of the Protestant economy computed in the previous subsection. We emphasize that in addition to using the same initial conditions, the counterfactual exercise employs the same parameters, and population growth function; the only difference is that beliefs in the counterfactual are given by the function $\pi^{C}(x)$ and not $\pi^{P}(x)$.

Figure 3 compares the percentage of output produced using the Malthusian technology over time in the two economies. The take-off date is the date when the share drops below 100 percent. The difference in religious beliefs delays the start of economic development by only one period-35 years. The transition takes as long to complete in the Catholic economy as in the Protestant economy.

Figures 4(a)-4(d) highlight other dimensions in which the development paths of the two economies differ. Figures 4(a) and 4(b) show that capital to output ratios are clearly higher and interest rates are clearly lower in the Catholic economy. After 1850, the capital to output 
Figure 4: Comparison between Catholic and Protestant Economy

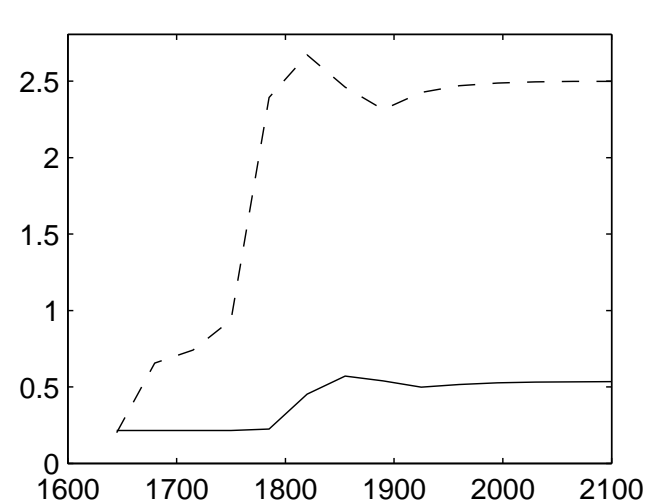

(a) Capital to output ratio

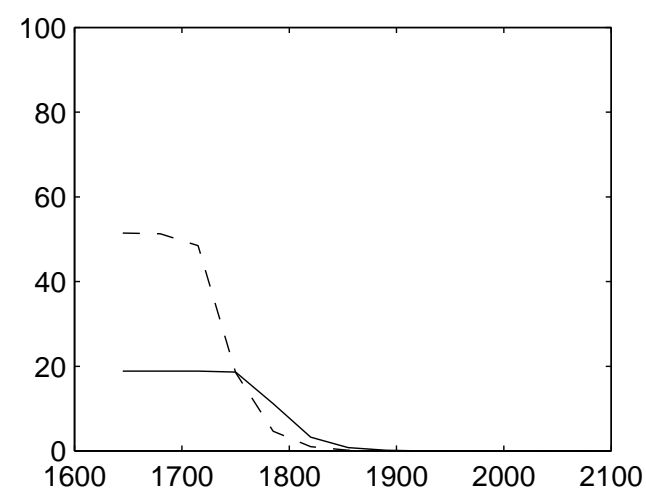

(c) Land value as $\%$ of wealth

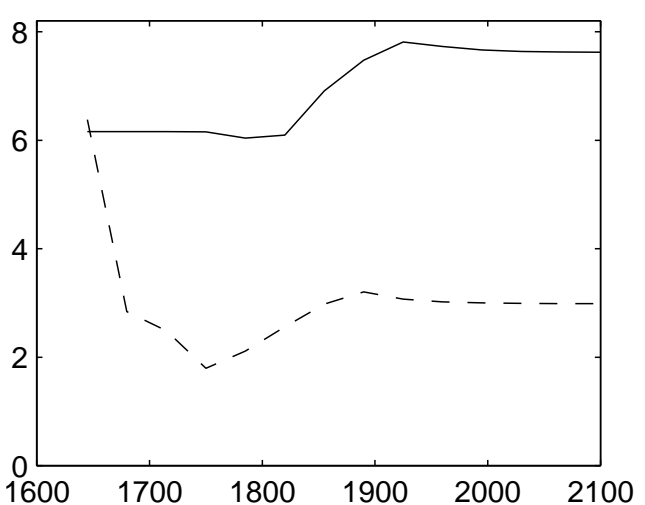

(b) Interest rate

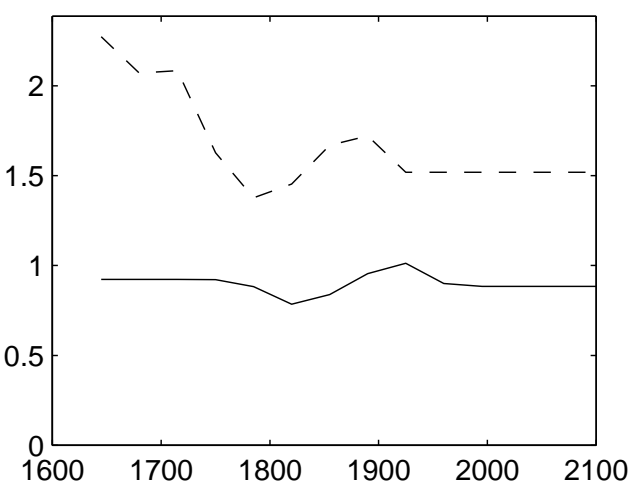

(d) Ratio of consumption by the old and the young

- Catholic

- - Protestant 
ratio is roughly 5 times greater in the Protestant country and the interest is more than 2 times greater in the Catholic country. These differences reflect the fact that saving is the main channel through which religion affects development in the model. The greater savings rate by young households in the Protestant economy also implies a much higher value of land there until it begins to industrialize, as shown in figure 4(c). Additionally, as the young households in the Protestant economy save a larger proportion of their income when young, both in the form of land and capital, the ratio of consumption when old to young is larger $(4(d))$.

\section{Sensitivity}

We now examine whether our findings are sensitive to the observations used to calibrate the model. The sensitivity analysis focuses on three sets of observations: the labor inputs, the capital to output ratio, and capital's share. We focus on these observations because measurement errors are very likely. Additionally, these are observations that are critical in determining the values of the religious belief parameters, which are the essence of the paper and which we have no independent information. We find that our results are robust to possible measurement problems associated with these observations.

\subsection{Labor Inputs}

We have two concerns with respect to the accuracy of the labor-input observations used in the baseline calibration. First, the Clark and von der Werf (1998) estimates of labor inputs are measured in days worked per year rather than total hours. In the baseline case, we did not adjust for the fact that the number of hours worked per day is far smaller than 24 . This suggests that the true difference in labor inputs in the pre-1645 period and the post-1850 period may be smaller than the baseline case. Second, the Clark and von der Werf labor 
Figure 5: Sensitivity Analysis: Labor Supplies

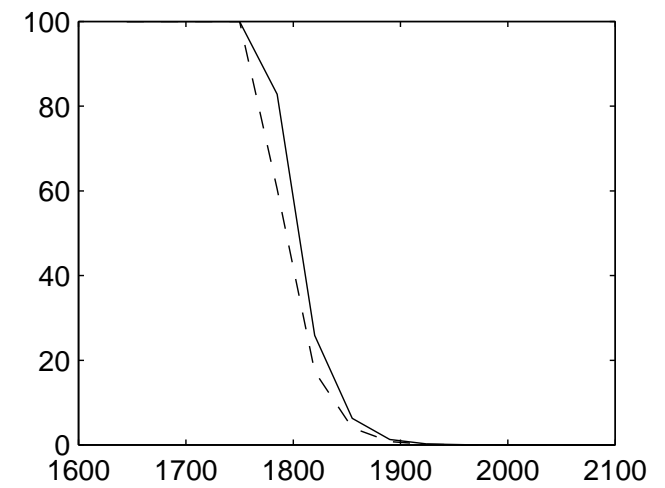

(a) Clark-van der Werf estimates

- Catholic

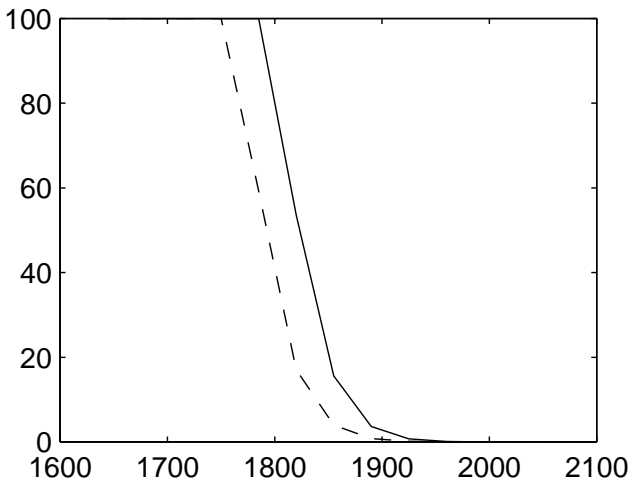

(b) Voth estimates

- - Protestant

input numbers are based on observations in the agriculture sector only. Voth (1998)[30] suggests there was a more significant increase in work days outside of the primary sector in the eighteenth century England. Whereas the Clark and von der Werf estimates imply a 1.13 factor difference in labor inputs between the two periods, the Voth estimates imply a 1.20 factor difference. This suggests that the true difference in labor inputs may be larger than the baseline case.

On account of these concerns, we recalibrate the model using the smaller historical differences associated with adjusting the Clark and von der Werf (1998) workday numbers, and using the larger historical differences estimated by Voth (1998). We adjust the Clark and von der Werf (1998) numbers to reflect an 11 hour workday, which is the length of the workday Voth (1998) estimates from court records for eighteenth century London. As figure 5(a) shows, the difference in the take-off dates between Catholic and Protestant economies disappears with the adjusted Clark and von der Werf labor inputs. The effect is smaller, as the calibrated parameter value of $\alpha \cdot V$ is smaller due to the smaller difference in hours worked between Catholic and Protestant households. The re-calibration to the Voth (1998) 
Figure 6: Sensitivity Analysis: Capital to Output Ratios

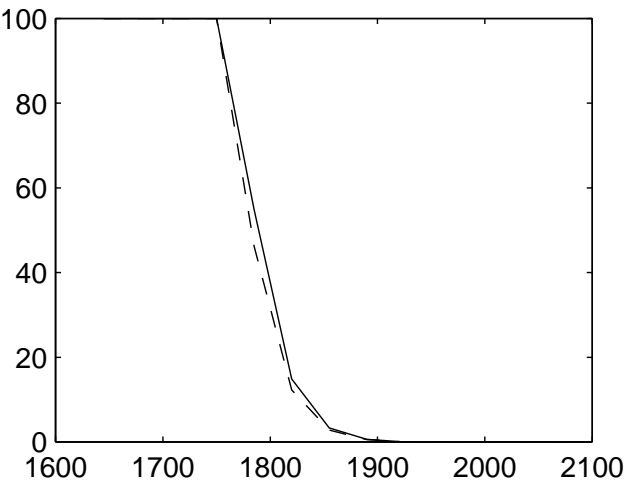

(a) Capital to output ratio of 4

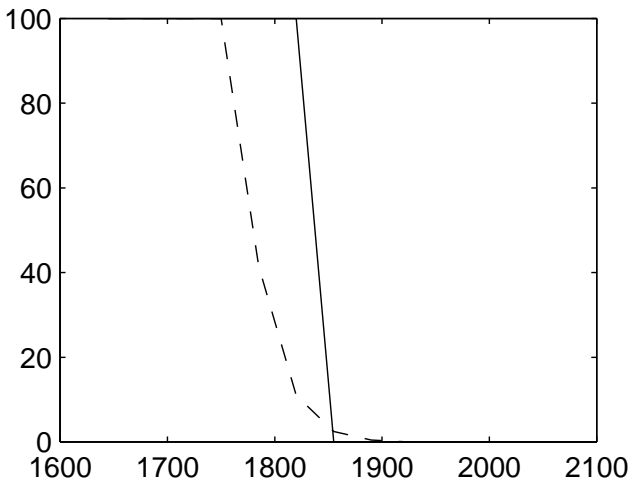

(b) Capital to output ratio of 2.25

estimates does not alter our findings. As figure 5(b) shows, the difference in take-off dates between Protestant and Catholic economies is still 35 years. We conclude from these exercises that our results are robust to labor inputs being poorly measured.

\subsection{Capital to Output Ratios}

There are discrepancies concerning historical estimates of the capital to output ratios for England that we were unable to resolve. The primary source of these estimates is Feinstein (1978). Feinstein's estimates are the basis of the capital to output ratios reported in Maddison (1995. p 65). Despite this, Maddison's estimates are not easy to reconcile with Feinstein's. Feinstein's, which apply to Great Britain over the 1830-1860 period range from a high of 7.3 in 1830 to a low of 4.2 in 1860. Maddison's, which apply to the United Kingdom over the 1890-1990 period, range from a low of 1 in 1890 to a high of 2 in 1990. For these reasons, it is appropriate to explore how our findings change when higher and lower capital to output ratios are used in the calibration.

Figures 6(a) and 6(b) show that the difference in take-off dates decreases as the capital 
to output ratio is increased. The capital to output ratio has important consequences for the value of the subjective discount factor, $\beta$, with a higher capital to output ratio implying a higher value for $\beta$. At the same time, a higher value for $\beta$ requires a lower value for $\alpha V$ in order to match the labor input observations. Consequently, a higher capital to output ratio has the effect of diminishing the importance of religious beliefs, $\alpha V$. This explains why the effect of religion on take-off dates is smaller when a higher capital to output ratio is used in the calibration.

Lowering the capital-output ratio, thus, would seem like a potential way to increase the delay in industrialization. However, it is not possible to lower the capital to output ratio much below 2.25, as the condition for an interior solution to a Catholic household's maximization problem, namely, $\beta \alpha V<1$, would be violated. A ratio of 2.25 is, thus, the approximate lower bound on the set of feasible capital to output ratios. For this ratio, the delay is 70 years. This leads us to conclude that 70 years is an upper bound of the range of plausible delays. ${ }^{15}$

\subsection{Capital's Share}

The capital share parameter value, $\theta$, in the Solow technology used in the calibration was taken from Hansen and Prescott (2002). They derive this value by computing the income paid to physical capital in the national accounts. A major line of research in the development and growth literature argues that other forms of capital, namely, human and organizational capital, are also important inputs in the production of goods and services. When capital is broadly defined to include both physical and intangible capital, its importance in production

\footnotetext{
${ }^{15}$ Another reason we believe that 70 years is an upper bound is that the implied annual interest rate in the Catholic economy is 13 percent. We have not been able to find interest rate data from France or Italy for the 17 th century, but our sense is that 13 percent is implausibly high.
} 
Figure 7: Sensitivity Analysis: Capital's Share

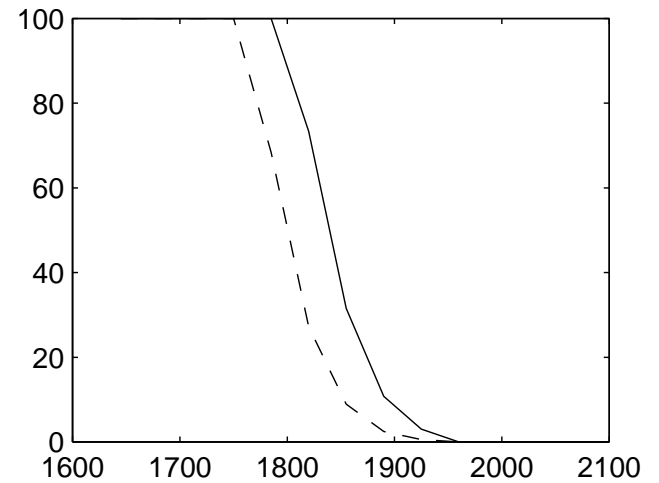

(a) Capital's share: $50 \%$

- Catholic

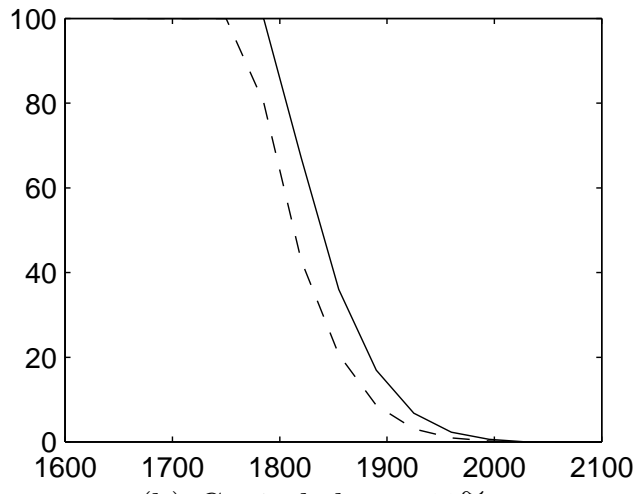

(b) Capital share: $60 \%$

- - Protestant

increases, as reflected by a larger coefficient on the capital input in the production function. Parente and Prescott (2000)[24], for instance, suggest that the share value for this broad capital stock could be as high as .60 .

In light of this possibility, we recalibrate the model economy to a higher capital share. Figure 7 shows the difference in take-off dates between the Protestant and Catholic economies for a capital share of .50 and $0.60 .{ }^{16}$ As can be seen, our finding is robust to the possibility that a large amount of capital in the economy goes unmeasured. The difference in take-off dates does not change as the capital share parameter increases. The main effect is to increase the length of time it takes to complete the transition for both economies.

\footnotetext{
${ }^{16}$ In re-calibrating to these higher share values, the value of $A_{S 1}$ is reset to ensure that the Protestant economy begins to industrialize in 1750
} 


\section{Conclusion}

This paper finds that differences in the way Catholics and Protestants viewed worldly achievements could perhaps explain why Northern Europe developed before Southern Europe, but it cannot explain why Europe developed before Latin American. Our counterfactual exercises indicate that 70 years is the upper bound to the length of the delay attributed to the differences between the two religions examen in the paper. In a certain sense, the finding is not surprising. Religion in our model primarily works to affect the start of economic development through an economy's savings rate and time input. Works by Hall and Jones (1999)[15] and Klenow and Rodriguez-Claire (1997)[19] have found that differences in savings rates and efficiency units of labor only account for a small fraction of current international income differences. These studies as well as others conclude that most of the differences in international income levels is attributed to differences in total factor productivity.

We emphasize that our paper examines only one difference between Catholic and Protestant faiths. There are surely other differences between the two religions that well may be important for the timing of the Industrial Revolution in England. For instance, Blum and Dudley (2001) argue that Protestantism facilitated the rise of impersonal trade because practitioners of that faith did not have the confessional whereby cheating could be forgiven. Gorski (2004)[13] argues that Protestant reformation had important implications for the agricultural surplus because it redistributed land away from the church and into the hands of private citizens who responded to market incentives. He further argues that the reformation eliminated the class structure in England, that served to retard innovation. Additionally, Williamson and Stutz (2001)[28] argue that Catholicism led to less protection for creditors because Catholicism viewed lending as a sin. These are all worthy hypotheses that could be and should be examined using calibration procedures. 


\section{References}

[1] B. Arrunada. The economic effects of christian moralities. Upublished Manuscript. Universitat Pompeu Fabra, 2004.

[2] Robert J. Barro and Rachel M. McCleary. Religion and economic growth. Unpublished manuscript, Harvard University, 2003.

[3] U. Blum and L. Dudley. Religion and economic growth: was weber right?, journal=.

[4] Azzi C and R. G. Ehrenber. Household allocation of time and church attendance. Journal of Political Economy, 83(1), 1975.

[5] B.R. Chiswick. The earnings and human capital of american jews. Journal of Human Resources, 18(3):313-336, 1983.

[6] G. Clark. Microbes and markets: Was the black death an economic revolution. Unpublished manuscript, University of California, Davis, 1998.

[7] G. Clark and Y. Van Der Werf. Work in progress? the industrious revolution. Journal of Economic History, 58(3):830-843, 1998.

[8] C.G. Ellison. Religious involvement and subjective well-being. Journal of Health and Social Behavior, 32(1):80-99, 1991.

[9] C. H. Feinstein. Capital formation in great britain. In P Mathias and M.M. Postan, editors, The Cambridge Economic History of Europe, volume 7 Part I. Cambridge University Press, London, 1978.

[10] R.B. Freeman. Who escapes? the relation of churchgoing and other background factors to the socioeconomic performance of black male youths from inner-city tracts. In B.F. Richard and J.H. Harry, editors, The Black Youth Employment Crisis. 1986. 
[11] Kemper Fullerton. Calvinism and capitalism: An explanation of the weber thesis. In Robert W. Green, editor, Protestantism, Capitalism, and Social Science: The Weber Thesis Controversy. D.C. Heath and Company, Lexington, Massachusetts, 1973.

[12] Douglas Gollin. Getting income share right. Journal of Political Economy, 110(2), 2002.

[13] Phil Gorski. The protestant reformation and economic hegemony: Religion and the rise of england and holland. University of Wisconsin Working Paper, 2004.

[14] Luigi Guiso, Paola Sapienza, and Luigi Zingales. People's opium? religion and economic attitudes. Journal of Monetary Economics, 50:225-282, 2003.

[15] Robert E. Hall and Charles I. Jones. Why do some countries produce so much more output per worker than others? Quarterly Journal of Economics, 114:83-116, 1999.

[16] G. Hansen and E. Prescott. Malthus to solow. American Economic Review, 92(4):1205$1217,2002$.

[17] L. R. Iannaccone. Introduction to the economics of religion. Journal of Economic Literature, 36(3):1465-1496, 1998.

[18] R. B. Ekelund Jr., R. F. Hébert, and R. D. Tollison. An economic analysis of the protestant reformation. Journal of Political Economy, 110(3):646-671, 2002.

[19] Peter J. Klenow and Andres Rodriguez-Clare. The neoclassical revival in growth economics: Has it gone too far? In B. Bernanke and J. Rotemberg, editors, NBER Macroeconomics Annual. MIT press, Cambridge, 1997.

[20] D. Landes. The Wealth and Poverty of Nations: Why Some Are So Rich and Some So Poor. Norton, 1998. 
[21] William E. Lunt. Papal Revenues in the Middle Ages. Columbia University Press, New York, 1934. Reprint. New York: Octagon Books, 1965.

[22] A. Maddison. Dynamic Forces in Capitalist Development: A Long-Run Comparative View. Oxfore University Press, New York, NY, 1995.

[23] L. R. Ngai. Barriers and the transition to modern growth. Mimeo, University of Pennsylvania, 1999.

[24] Stephen Parente and Edward Prescott. Barriers to Riches. The MIT Press, Cambridge, Massachusetts, 2000.

[25] Stephen Parente and Edward Prescott. A unified theory of the evolution of international income levels. In P. Aghion and S. Durlauf, editors, Handbook of Development Economics. 2005.

[26] A. Shleifer R. La Porta, F. Lopez-de-Silanes and R.W. Vishny. Trust in large organizations. American Economic Review, 87(2):333-338, 1997.

[27] Kurt Samuelsson. Religion and Economic Action: The Protestant Ethic, the Rise of Capitalism, and the Abuses of Scholarship. University of Toronto Press, Toronto, 1993.

[28] R. Stulz and R. Williamson. Culture, openness and finance. NBER working paper 8222, 2001.

[29] Richard H. Tawney. Religion and the rise of capitalism. Harper and Row, New York, 1926.

[30] Hans-Joachim Voth. Time and work in eighteenth-century london. The Journal of Economic History, 58(1):29-58, 1998. 
[31] Max Weber. The Protestant Ethic and the Spirit of Capitalism. Free Press, New York, 1958. Translated by Talcott Parsons. 